\title{
非構造壁を内蔵する鉄筋コンクリート造架構の構造性能に関する研究 STRUCTURAL PERFORMANCE OF REINFORCED CONCRETE FRAME WITH NON-STRUCTURAL REINFORCED CONCRETE WALLS
}

\author{
杉山智昭*, 松 崎育弘**, 中野克彦*** \\ Tomoaki SUGIYAMA, Yasuhiro MATSUZAKI and Katsuhiko NAKANO
}

\begin{abstract}
This paper proposed a method to estimate the structural performance (stiffness, capacity, failure mode and ductility) of the Reinforced Concrete (RC) frame with cast-in-place non-structural $R C$ walls (spandrels, sidewalls and mullions): The shear-loading tests for onestory one-span $R C$ frame with non-structural walls were conducted to investigate the influence of non-structural walls on structural performance of the RC frame. The shear resistant mechanism of the RC frames was clarified from the test and the finite element analysis (2-D non-linear analysis). The load-displacement relationship of the RC frame can be predicted by this method verified with the shear resistant mechanisms.
\end{abstract}

\author{
Keyword : Reinforced Concrete, Non-structural wall, Frame, Experiment, Finite element method \\ 鉄筋コンクリート造, 非構造壁, 架構, 実験, 有限要素法解析
}

\section{1.はじめに}

柱および梁で構成される架構型の鉄筋コンクリート造建物では, 様々な用途から，腰壁・垂れ壁・袖壁・方立て壁が混在した形状の 非構造壁が構面内に設けられる。非構造壁は, 柱・梁の構造部材と 同時に施工されるのが一般的なため，架構に剛接合されることで構 造体との忘力伝達が発生し，地震時の建物挙動に多大な影響を与え ることになる。この影響は，構造体(柱)に取り付く部分の壁板形状 から(1)腰壁・垂れ壁的な挙動，(2)袖壁的な挙動，(3)方立て壁的な举 動とに分けられる。これらの挙動は, 地震が発生する毎に, (1)変形 が拘束された柱のせん断破壊(いわゆる短柱化)や(2)剛性が高くなり 応力が集中して生じた柱のぜん断破壊として報告されており ${ }^{1)}$ ，非 構造壁が架構の構造性能に悪影響を与えるとみなされる傾向が強く なっている。しかし，地震被害の中には，壁板が構造部材よりも先 に破壊寸ることで架構の損傷が軽微になった報告 ${ }^{2)}$ もれており， 一概に非構造壁が耐震上不利であると断定する事もなさそうである。

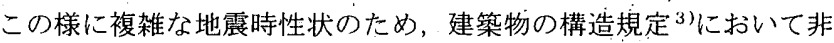
構造壁の取り扱いは，『影響が少ない場合，柱及び梁の剛性及び応 力ならびに断面の検討にはその存在を無視して良い。』『(影響の ある場合)剛域を考慮の上，曹げ変形およびせん断変形に基づきは り及び柱の剛性や応力を計算する。』とが示されているが具体的な 設計手法は示されておらず，非常に暧昧な状況となっている。この
ため, 既存鉄筋コンクリ ○造建物の耐震診断4)、においては，例 えば垂れ壁・腰壁が取り付いた柱は，壁端から壁端までをクリアス パンとする短柱として評価し，曲げ耐力を過大に，かつ，勒性能を ほぼ無視するなどといった，精度に劣る評価方法を取らざるを得な い状況である。これらは，早急な寒施が望まれているにもかかわら ず，非構造壁が多く存在する集合住宅の耐震診断と補強を遅らせて いる原因にもなっており，適切な非構造壁の評価方法が求められる。 一方, 非構造壁と構造部材の応力伝達をディテールの面から回避 する事を目的とした, 『構造用スリット』と呼ばれる目地について 使用が推奨されている。しかし，この方法は，非構造壁を構造体か ら切り離すことで, 結果的に架構全体の㓮性と耐力を共に低下させ る恐れも併せ持っている。また，スリットの使用には，目地部分の 防水と耐火の問題, 配筋やコンクリート打設など施工上の問題も指 摘されている。更に, 壁板の一部の厚さを薄くする，いわゆる『部 分スリット』の場合には, 非構造壁の存在による力学的影響は無視 し得ないことが示されており ${ }^{5)}$, 構造用スリットを用いる場合にも 適切な評価と使用が必要となる。

本研究では，構造体に剛接合する非構造壁が $\mathrm{RC}$ 架構の構造性能 (風性，耐力，破壊モード，変形能等)に与える影響について明らか にし，非構造壁の取り扱い方法の提案を目的としている。本論文で は, 特に垂れ壁・腰壁的举動となる非構造壁を内蔵する架構を対象

\footnotetext{
*東京理科大学大学院工学研究科建築学専攻 大学院生.工修

** 東京理科大学工学部建築学科'教授. 工博

****東京理科大学工学部建築学科 助手
}

Graduate School, Dept. of Architecture, Faculty of Eng.; Science Univ. of Tokyo, M. Eng.

Prof., Dept. of Architecture, Faculty of Eng., Science Univ. of Tokyo, Dr. Eng: Assistant, Dept. of Architecture, Faculty of Eng., Science Univ. of Tokyo 
表 1 試験体一覧

\begin{tabular}{|c|c|c|c|c|c|c|c|}
\hline \multirow[b]{2}{*}{ No. } & \multirow[b]{2}{*}{ 試験体名 } & \multirow{2}{*}{$\begin{array}{l}\text { コンク } \\
\text { リート } \\
\text { 強度 } \sigma \\
{\left[\mathrm{N} / \mathrm{mm}^{2}\right]}\end{array}$} & \multicolumn{3}{|c|}{ 柱部 } & \multicolumn{2}{|r|}{ 壁部 } \\
\hline & & & 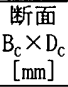 & 主筋 & $\begin{array}{l}\text { せん断 } \\
\text { 補強筇 }\end{array}$ & 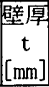 & 補強筋 \\
\hline $0-0$ & $F-53-0$ & 26.8 & \multirow{8}{*}{$\begin{array}{c}240 \\
\times \\
240\end{array}$} & \multirow{8}{*}{$\frac{12}{\mathrm{D} 13}$} & \multirow{4}{*}{$\begin{array}{l}D 6 @ 50 \\
(0.53 \%)\end{array}$} & - & - \\
\hline $1-1$ & $S W-53-6$ & 33.0 & & & & 60 & D6@200(0.27\%) \\
\hline $1-2$ & NWSM-53-4 & 24.7 & & & & 40 & $D 4 @ 105(0.30 \%)$ \\
\hline $1-3$ & NWTKM-53-4 & 24.1 & & & & 40 & D4@ $105(0.30 \%)$ \\
\hline $2-1$ & NWTK-38 & \multirow{4}{*}{27.8} & & & \multirow{2}{*}{$\begin{array}{l}D 6 @ 70 \\
(0.38 \%) \\
\end{array}$} & 40 & D4@105(0.30\%) \\
\hline & $-4 \cdot 8$ & & & & & 80 & $D 4 @ 105(0.15 \%)$ \\
\hline $2-2$ & NWTK-19 & & & & D6@140 & 40 & D4@ $105(0.30 \%)$ \\
\hline & $-4 \cdot 8$ & & & & $(0.19 \%)$ & 80 & $D 4 @ 105(0.15 \%)$ \\
\hline
\end{tabular}

表 2 使用鉄筋降伏強度一覧 $\left(\sigma_{y}\right)\left[\mathrm{N} / \mathrm{mm}^{2}\right]$

\begin{tabular}{c|c|c|c|c}
\hline 試験体No. & $0-0$ & $1-1$ & $1-2,1-3$ & $2-1,2-2$ \\
\hline \hline 柱主筋(D13:SD345) & 384 & 388 & 350 & 384 \\
\hline \hline 柱せん断補強筋 (D6:SD295) & 335 & 402 & 292 & 303 \\
\hline 壁補強筋 & - & $402(\mathrm{D} 6)$ & $250(\mathrm{D} 4)$ & $252(\mathrm{D} 4)$ \\
\hline
\end{tabular}

として, 架棈の復元力包絡線(強度一変形関係)の評価方法を, 柱と 壁板のせん断力に対する抵抗機構に基づき提案する。

\section{2. 実駼}

実験は，第 1 シリーズとして，架構内に存在する壁板の違いが架 構の構造性能に与える影響, 特に非構造壁が破壊する場合の影響を 明らかにするために計画した。第 2 シリーズは，垂れ壁・腰壁的挙 動を示す非構造壁を内蔵する架構について取り上げ，更に構造性能 評価に必要な知見を得るために計画している。

\section{1 実験概要 (共通要因)}

表 1 に試験体一覧，表 2 に使用鉄筋材料一覧，図 1 に試験体形 状及び配筋図を示す。試験体は 1 層 1 スパンの架構で，その大きさ は実大の約 $1 / 3$ である。架構内の壁板は柱と梁に㴊接合させている。

共通要因として，柱芯々寸法は(I)2000 $\mathrm{mm}$, 壁下端からせん断 力加力点までの距離は $1400 \mathrm{~mm}$ とした。また，柱断面 $\left(B_{C} \times D_{C}\right)$ は $240 \times 240 \mathrm{~mm}$ で, スタブ梁断面 $\left(B_{B} \times D_{B}\right)$ は $800 \times 600 \mathrm{~mm}$ と剛体に近 い形状とした。柱主筋は 12-D13(SD345), 壁せん断補強筋は縦, 横 ともにD4@105とし，壁筋は，長さ $210 \mathrm{~mm} て ゙$ 柱と梁に定着させた。 また，スタブ梁主筋は $2 \times 6-\mathrm{D} 22$, 補強筋はD13(SD295)@100( $p_{w}=$ $0.31 \%$ )とした。試験体は計 6 体を計画した。

加力は，柱の上部に一定の軸力 $\left(N=2 \cdot B_{C} \cdot D_{C} \cdot \sigma_{B} / 6\right)$ を保ち，試験 体上部のスタブ梁芯位置に，左右の押し引きの荷重が等しくなるよ
$\mathrm{N} / 2$ $\left\lceil\zeta^{N / 2}\right.$

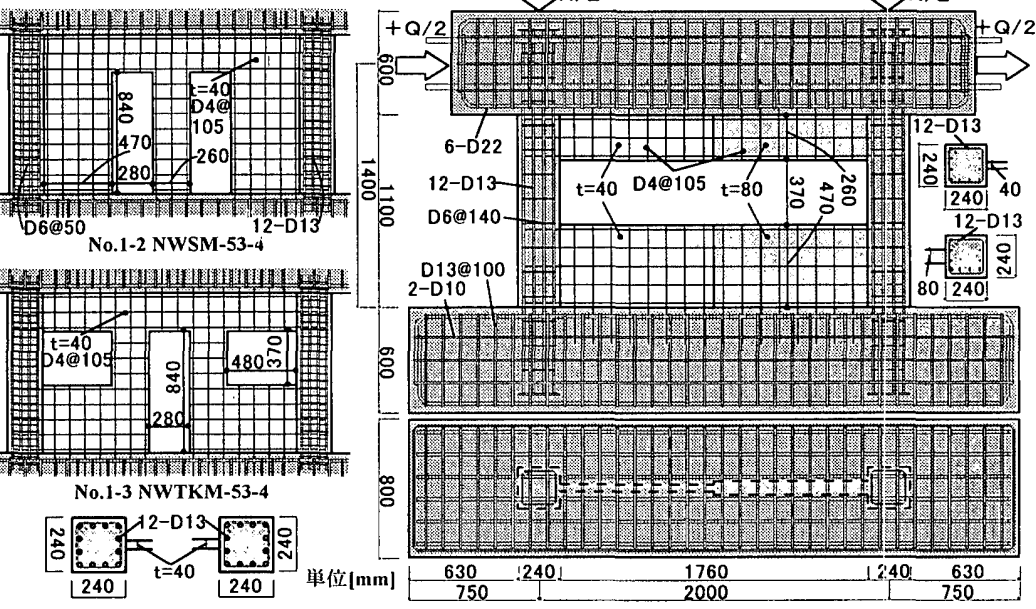

図 1 試験体形状図(右 No.2-2)

う変位制御の漸増繰り返しで載荷した。

\section{2 第 1 シリーズ(架構内の壁板の影暗 : No. 0-0〜No. 1-3)}

第 1 シリーズの変動要因は, 壁板が架構の構造性能に与える影 響を明らかにするために架構内の壁板形状(No.0-0〜No.1-3)とした。 架構内の壁板形状は, 純ラーメン試験体(No.0-0), 無開口耐震壁試 験体(No.1-1)，および集合住宅の北側構面を想定した非溝造壁試験 体(No.1-2,No.1-3 ; 図 1)を設定した。No.1-2 試験体は袖壁的举動を, No.1-3 試験体は垂れ壁・腰壁的挙動を想定して計画している。

表 3 に実験結果一覧，図 2 に非構造壁試験体の破壊状況，図 3 に非構造壁試験体のせん断力 $(Q)$ 一層間変位 $(\delta)$ 関係を示す。各試 験体の破壊状況は，地震被害 ${ }^{2}$ の報告と一致しており，破壊モ一 ドは，No.1-1(耐震壁)が壁板せん断破壊，No.0-0(frame),No.1-2,No.1$3\left(p_{w}=0.53 \%\right)$ が曲げ降伏となった。No.1-2 (袖壁試験体)の破壊は，Q $=150 \mathrm{kN}$ 付近で袖壁にせん断ひび割れが発生し，その後柱にせん断

\begin{tabular}{|c|c|c|c|c|c|}
\hline \multirow[b]{2}{*}{ No. } & \multirow[b]{2}{*}{ 試験体名 } & \multirow{2}{*}{$\begin{array}{c}\text { 初期岡川性 } \\
\mathrm{K} \\
{[\mathrm{kN} / \mathrm{mm}]}\end{array}$} & \multicolumn{2}{|c|}{ 最大耐力 $\mathrm{Q}_{\text {matx }}$ (層間変形) } & \multirow{2}{*}{ 破壊モード } \\
\hline & & & $\begin{array}{c}\text { 正栽荷 } \\
{[\mathrm{kN}]([\mathrm{mm}])}\end{array}$ & $\begin{array}{c}\text { 負載掎 } \\
{[\mathrm{kN}]([\mathrm{mm}])}\end{array}$ & \\
\hline $0-0$ & $F-53 \sim 0$ & 80 & $245(20.64)$ & $244(17.14)$ & 曲け降伏 \\
\hline $1-1$ & $\mathrm{SW}-53-6$ & 750 & $1025(7.79)$ & $871(3.52)$ & 壁部せん断破壊 \\
\hline $1-2$ & NWSM-53-4 & 235 & $347(12.12)$ & $340(7.04)$ & 曲げ降伏 \\
\hline $1-3$ & NWTKM-53-4 & 155 & $318(13.09)$ & $331(14.10)$ & 曲げ降伏 \\
\hline $2-1$ & NWTK-38-4・8 & 127 & $332(11.61)$ & $316(13.19)$ & 曲げ降伏後せん断破壊 \\
\hline $2-2$ & NWTK-19-4-8 & 121 & $275(7.04)$ & $266(5.28)$ & 柱せへ断破壊 \\
\hline
\end{tabular}

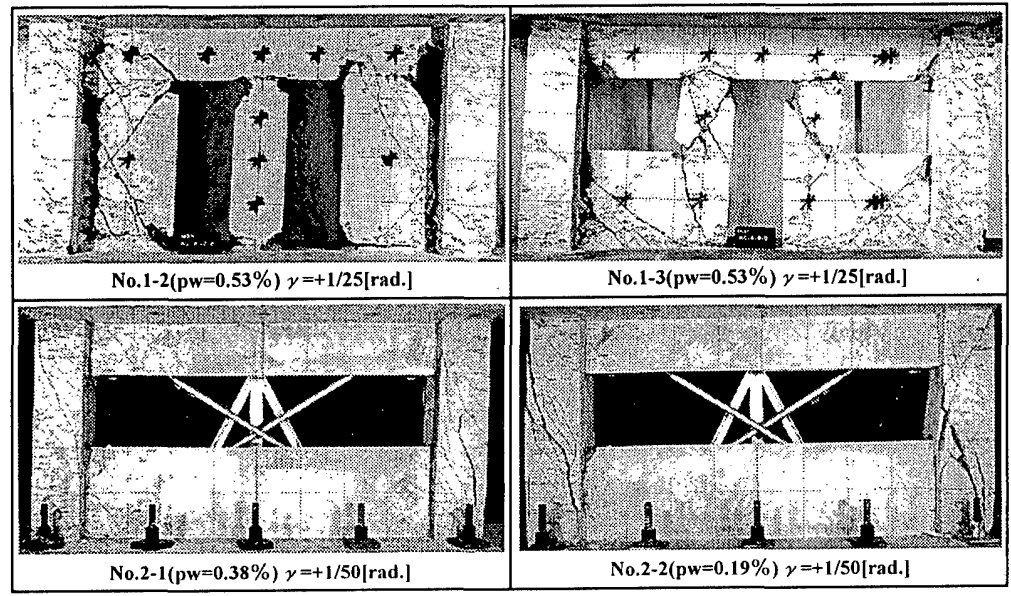

図 2 破壊状況

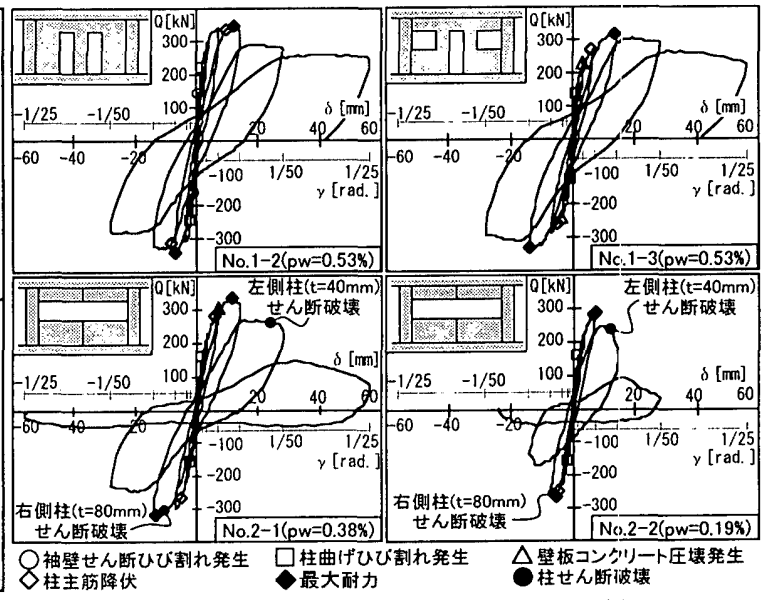

図 3 せん断力 $(\mathrm{Q})$ 一層間変位 $(\delta)$ 関你 


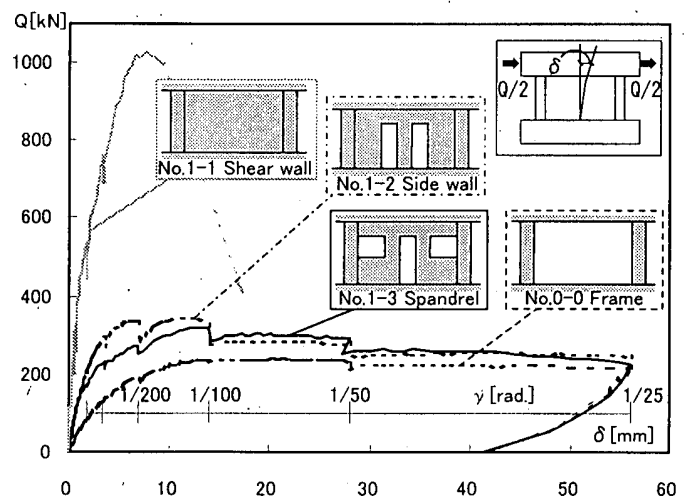

図 4 せん断力 $(\mathrm{Q})$ 一層間変位 $(\delta)$ 関係包絡線

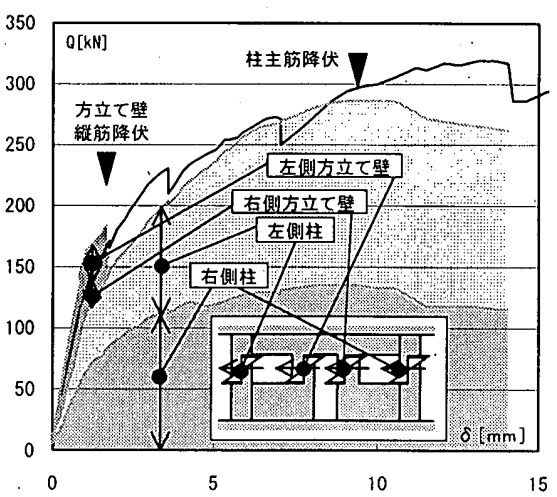

図 5 負担せ之断力一層間変位関係包絡線

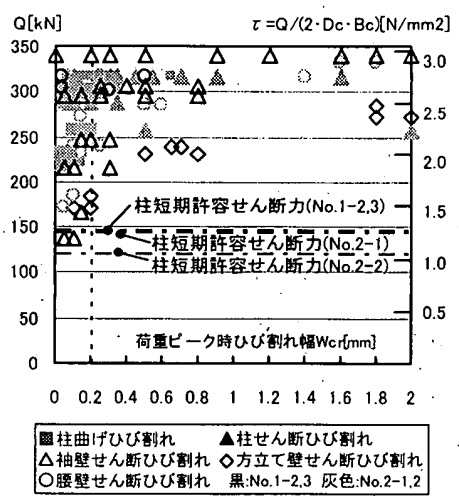

図6“せん断カーひび割れ幅関係
ひび割れが進展し，最大耐力付近で柱と袖壁が滑るようなひび割れ が著しくなった。No.1-3(垂れ壁・腰壁試験体)の破壊は, 非常に小 さい荷重 $(Q=10 \sim 40 \mathrm{kN})$ で, 引張応力の生じている柱と壁板の接合 面にひび割れが生じ，その後，柱の曲げとせん断ひび割れ，壁せん 断ひび割れ及び壁板コンクリート圧壊が発生した。この壁板コンク リート圧壊は， $Q=250 \sim 300 \mathrm{kN}$ に発生しているが，柱の曲げ降伏 (最大耐力)以降に進展が著しくなる傾向であった。

図 4 に架構内の壁板を変動要因とする frame 試験体(No.0-0), 耐 震壁試験体(No.1-1) および非構造壁試験体(No.1-2,3)のせん断力 $(Q)$ 一層間変位 $(\delta)$ 関倸包絡線を示す。壁板の存在により, 非構造壁試 験体の剛性は，曲げ降伏まで， frame 試験体よりも非常に大きくな. っている。その曲げ耐力は耐震壁試験体ほどの上昇はなく, 曲げ降 伏以降, 負担せん断力は壁板の破壊に伴って緩やかに frame 試験体 の耐力に近付き, 変形能が層間変形角 $(\gamma)=1 / 25[\mathrm{rad}$.] 越える性状 となった。この様に非構造壁が存在する場合でも柱せん断破壊は生 じず，剛性・耐力・エネルギー吸収量の増加が見られた。

図 5 に No.1-3 試験体の負担せん断力ー層間変位関係を示す。柱 と方立て壁の負担せん断力は, 柱と方立て壁の各々の断面に, 平面 保持を仮定して求めた抵抗モーメントより算出した。抵抗モーメン トの計算には, 空開口の上下端にある柱主筋と壁縌筋の歪みを用い

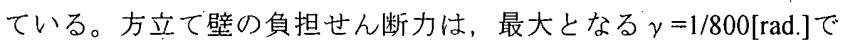
も左右合わせて $35[\mathrm{kN}]$ 程度の小さい值であった。更に, 最大耐力 付近の方立て壁は，著しくひび割れが拡大して負担せん断力の低下 が想定されるため, 架構の構造性能は, 柱と柱に付帯する壁板(腰 壁・垂れ壁的，袖壁的举動)の性状が大きな割合を占めるといえる。

\section{3 第 2 シリース（垂れ壁・腰壁試験体：No. 1-3. No. 2-1, No. 2-2）}

第 2 シリーズでは，更に垂れ壁・腰壁的な挙動を示寸非構造壁を 内蔵する架構の性状を検討するため実験を行うた。No.2-1 及び No.2-2 は, No.1-3 が柱と柱に付帯する壁板の性状が支配的である ことから，図1に示すとおりの垂れ壁と腰壁を内蔵する形状とした。 No.1-3 を含めて, 変動要因は, 柱せん断補強筋比を $0.53,0.38$, $0.19 \%$ の 3 水準, 壁厚を $40 \mathrm{~mm}\left(t / B_{C}=1 / 6\right)$ と $80 \mathrm{~mm}\left(t / B_{C}=1 / 3\right)$ の 2 水準に設定した。なお, 壁板は, 正載荷と負載荷の加力方向によ って壁厚の差異が生じるように, No:2-1，2 試験体の左側半分を $40 \mathrm{~mm}\left(t / B_{C}=1 / 6\right)$, 右側半分を $80 \mathrm{~mm}\left(t / B_{C}=1 / 3\right)$ とした。

図 2 に破壊状況, 図 3 にせん断力 $(Q)$ 一層間変位 $(\delta)$ を示す。 No.2-1,2 の破壊状況とQ- $\delta$ 関係は, No.1-3 とほぼ同様の性状であ り, 最終的に No.2-1( $\left.p_{\mathrm{w}}=0.38 \%\right)$ が曲げ降伏後のせん断破壊, No.2-

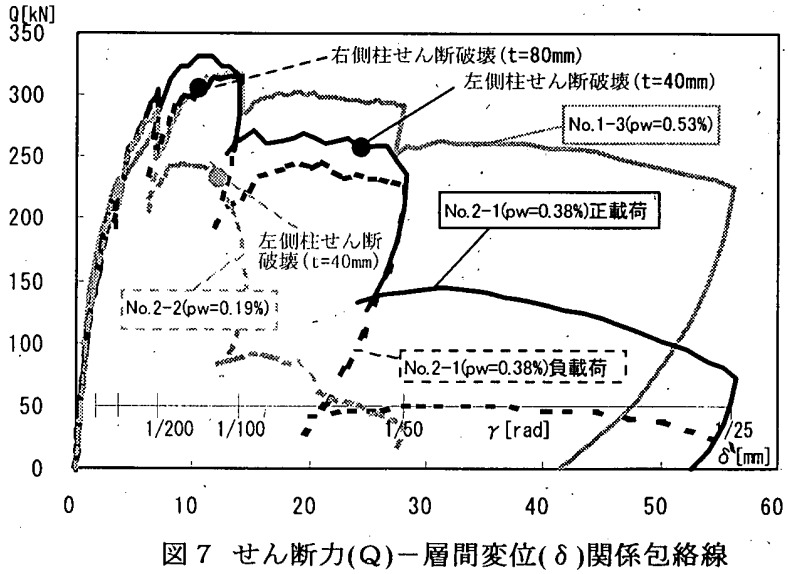

$2\left(p_{w}=0.19 \%\right)$ が曲げ降伏前のせん断破壊となった。壁の破壊は, 壁 厚 $(t) 40 \mathrm{~mm}$ でひび割れとコンクリート压壊が生じたが，壁厚 $(t) 80 \mathrm{~mm}$ では柱一壁接合面のひび割れ以外は観察されなかった。そ して，柱せん断破壊の発生により耐力は著しく低下している。

ここで, 損傷性能について検討を行う。図 6 に非構造壁試験体 (No.1-2,No.1-3 を含む)の層せん断力 $(Q)$ 一ひび割れ幅 $(W C r)$ 関係を示 す。ひび割れは, 柱のみの短期許容せん断力（RC 規準 ${ }^{6)}$ で計算） を越えた荷重で発生しており, 短期許容応力度で損傷の限界を検討 できる事を示している。壁板のひび割れ発生は柱よりも早く，その 口開きも大きくなる傾向であった。また，No.1-3 試験体の縌開口 (扉開口)周囲にある方立て壁の損傷は，垂孔壁・腰壁よりも著しく なっている。

図 7 に垂れ壁・腰壁的挙動を示す試験体のせん断補強筋量 $\left(p_{w}\right)$ を 変動要因としたせん断力 $(Q)$ 一層間変位 $(\delta)$ 関係を示す。なお, No.2-1 $\left(p_{w}=0.38 \%\right)$ 試験体は, 正・負載荷の両方を示し, 腰壁が柱を 拘束してクリアスパンが最も短くなる時の柱について，壁厚の影響 を検誩する。せん断補強筋量の増加に伴い, 破壊モードはせん断破 壊先行型から曲げ降伏先行型へ移行し, 世九断破壊時の変形角が大 きくなり, 変形性能は向上している。また, 壁厚の違い(No.2-1)に 着目すると，壁厚の变化による耐力の差は認められないが，負載荷， 時 $(l=80 \mathrm{~mm})$ 右側柱のせん断破壊が $\gamma=1 / 100 \mathrm{rad}$. 付近, 正載荷時 $(t=40 \mathrm{~mm})$ 左側柱のせん断破壊が $\gamma=1 / 50 \mathrm{rad}$. 付近となり, 壁板の圧壊 によって変形性能は向上している。

更に壁厚の違いによる影響を考察するため;, 図 8にNo.2-1 試験 体の柱主筋及びせん断補強筋歪み分布を示す。壁厚 $(t)=40 \mathrm{~mm}$ は正 載荷における左側柱, 壁厚 $(t)=80 \mathrm{~mm}$ は負載荷における右側柱であ 
り，柱と腰壁の間に圧縮応力が生じる時の性状である。主笳の歪み は，柱一壁接合面にひび割れが発生した区間と開口区間で勾配があ り，せん断補強筋の歪みも，同じ区間で生じている。この主筋の歪 み量が最も大きい位置は，壁厚によらず壁端から $D_{C} / 2$ の範囲内に 存在している。そして主筋降伏後，主筋およびせん断補強筋の歪み は，壁板の圧壊した $t=40 \mathrm{~mm}$ の場合，腰壁の奥側で增加しておりク リアスパンの増大がみられる。なお，これらの傾向は，柱と垂れ壁 間に圧縮応力の伝達がある場合も同様に観察されている。

この様に, 構造体(柱)のせん断補強が充分な場合, 非構造壁を 内蔵する架構は, 非構造壁の存在が悪影響を及ぼさず, 剛性, 耐力 およびエネルギー吸収量が純ラーメンよりも上昇する性状となるこ とを示した。これより，非構造壁を内蔵する架構の設計は，柱と壁 板の応力伝達を敢えて無くす方法ではなく，壁板の破壊を許容した 設計法も選択できると考えられる。これ以降では, 特に, 垂れ壁・ 腰壁的な挙動を示す非構造壁を内蔵する架構(No.1-3,No.2-1 および No.2-2)を対象にして，構造設計および耐震診断を行う際に重要と なる, 架構の復元力包絡線の評伍法を抵抗機構に則して構築する。

\section{3. 有限要素法解析}

柱と壁板のせん断力に対する抵抗機構を明確にするため, 内部态 力状態の把握が可能である有限要素法解析を行う。ここでは更に, 壁厚を変動させたパラメトリック解析を行うことで, 非構造壁が架 構の剛性および耐力に与える影響をより明確する。

\section{1 解析概要}

図 9 に要素分割図及び接合部要素設定模式図を示す。解析は，コ ンクリート，鉄筋および付着の材料非線形を考慮した 2 次元有限要 素法解析プログラム7)を使用した。コンクリート要素は，8節点 四角形の弹塑性要素で, その 2 軸応力下の応力度 $(\sigma)$ 一ひずみ度 $(\varepsilon)$ 関係は Darwin and Pecknoldによる等価一軸ひずみ度に基づく直 交異方性モデルを修正して用い8，破壊条件は Kuper らの実験結果 を修正した Darwin のモデルを用いた。柱主筋は鉄筋線材要素，柱 と壁のせん断補強笳はコンクリート要素内に一様に分布するとした 鉄筋積層要素(付着完全固定)でモデル化し，柱主筋とコンクリート の付着は各要素間にボンドリンクを設定してモデル化した。さらに, 柱, 梁および壁板の各部材接合面には，局所的なひび割れと鉄筋の ダボ抵抗をモデル化するため, クラックリンクおよび, 文献 9）の せん断力ーずれ関倸を用いたダボバネを設定した。なお，引張応力 の生じる柱一壁接合面は, 荷重初期にひび割れが生じていることか ら,クラックリンク及びダボバネは設定せず, 応力の伝详がないも のとした。また, 壁板の厚さは, 試験体の左右で同一の厚さとした。 材料の機械的特性は，実験の材料試験結果を用いている。

\section{2 解析の検証}

図 10 に実験(No.1-3)と解析 $(\mathrm{t}=40 \mathrm{~mm})$ を比較したせん断力 $(Q)$ 一層 間変位 $(\delta)$ 関係を示す。解析の破壊状況は，実験で観察された特徵 的なひび割れ、コンクリート圧壊等, 破壊の発生箇所および発生荷 重とよい対応を示した。Q- $\delta$ 関倸においても，解析結果は，実験 の剛性低下状況を良く表現している。そして, 図 10 中に示すとお り, 内部の忘力状態を示す柱主筋, せん断補強筋(測定位置は図 8 に示す)等の歪み性状も実験と対応する結果となっており, 解析結 果は，実験結果を良好に表現し，内部の抵抗機構を検討する有効な
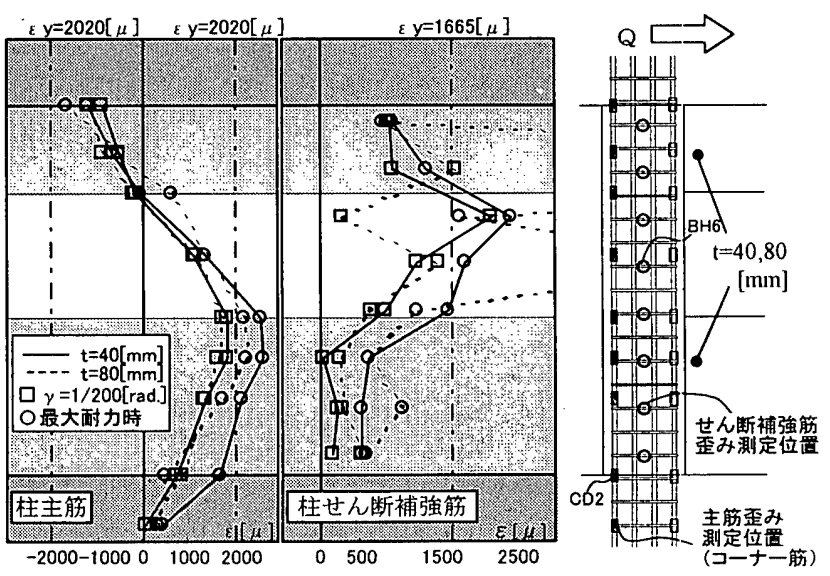

図 8 No.2-1 (pw=0.38\%)柱主箭・せん断補強筋歪み:分布

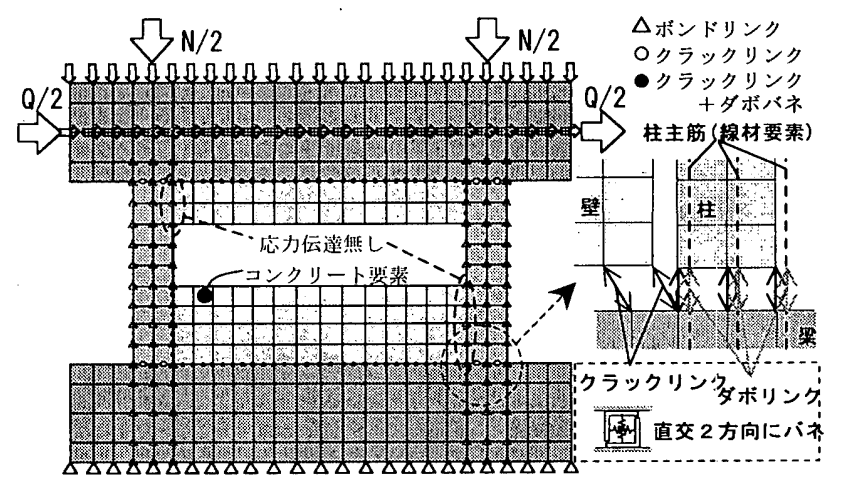

図 9 有限要素法解析要素分割図及び接合部要素設定模式図

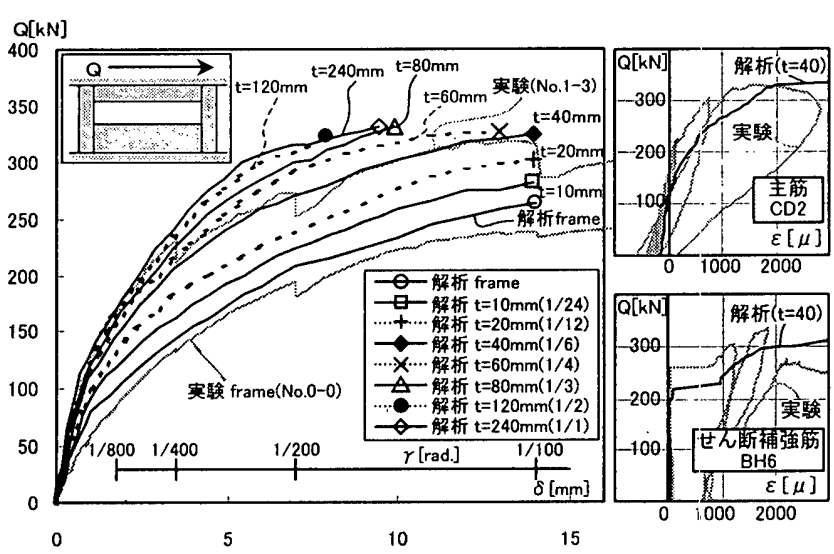

図 10 解析実験比較・壁厚変動解析結果せん断力一水平変位関係

表 4 解析変動要因および解析結果一覧

\begin{tabular}{|l||l|l|l|l|l|l|l|l|l|l|l|l}
\hline 壁厚 $(\mathrm{t})[\mathrm{mm}]$ & 10 & 12 & 16 & 20 & 30 & 40 & 60 & 80 & 100 & 120 & 160 & 240 \\
\hline
\end{tabular} \begin{tabular}{l|l|l|l|l|l|l|l|l|l|l|l|l}
\hline \hline 初期剛性 $[\mathrm{kN} / \mathrm{mm}]$ & 112 & 115 & 121 & 124 & 135 & 142 & 154 & 163 & 169 & 1.75 & 183 & 192 \\
\hline \hline
\end{tabular} \begin{tabular}{c|c|c|c|c|c|c|c|c|c|c|c|c|c|}
\hline 最大耐力 $[\mathrm{kN}]$ & 280 & 288 & 292 & 303 & 315 & 323 & 326 & 332 & 319 & 323 & 331 & 331 \\
\hline
\end{tabular}

手段といえる。

\section{3 パラメトリック解析}

壁板の厚さを变動要因とする解析を行い, 壁厚 $(t)$ の変化による剛 性・耐力の変化を検討寸る。非構造壁の厚さは, 左右で同一とし, 表 4 に示寸とおり， $10 \mathrm{~mm}$ から $240 \mathrm{~mm}$ まで変動させた。

パラメトリック解析のせん断力 $(Q)$ 一層間変位 $(\delta)$ 関係の一例を 図 10 に，初期剛性および而力一覧を表 4 に示す。なお，解析は柱 主筋降伏が降伏した時点で終了させた。柱開口区間のひび割れは全 ての解析試験体で同様な性状であり，壁が厚くなるにつれて壁板の 
ひび割れとコンククリートの圧壊域は小ざくなった。初期剛性および 最大耐力は，壁厚が厚くなるに従い上昇しているが，耐力の上昇は, 壁厚 $(t)=40 \mathrm{~mm}$ を越えると頭打ちになっている。これは，壁板が非 常に薄い場合にはクリアスパンの増大が認められるが， $t / B_{C}$ が $1 / 6$ 以上となる実建物の実用範囲内の厚さを想定すると，クリアスパン は著しく変化せず，曲げ耐力が変わらないものと考えられる。

\section{4. 内部応力状態の検討}

柱と壁板の抵抗機構に則した構造性能評洒法の提案を行うため, 実験および解析より内部の応力状態について検討する。

\section{1 応力の流れと柱モーメント分布}

図 11 に解析 $(t=40 \mathrm{~mm})$ のコンクリートの主応力図, 実験(No.2-1； $t=40 \mathrm{~mm}, t=80 \mathrm{~mm})$ と解析 $(t=10,40,240 \mathrm{~mm})$ の柱モーメント分布を 示す。解析の主応力は，コンクリート要素の内部積分点における圧 縮応力であり, 線の長さは大きさ, 線の方向は主応力方向を示して いる。図より、コンクリートの圧縮束は; 柱一壁接合面に圧縮応力 の伝達がある壁板とその壁板に変形を拘束された柱開口区間に存在 している。そして, 壁板圧縮束の角度(コンクリートの主応力方向) は，垂れ壁，腰壁共に $45^{\circ}$ に近い角度を示している。なお，これ らの圧縮束の形成状態や角度は，壁厚によって变化は生じていない。 図 11 に示す柱モーメント分布より応力の流れを更に検討する。 実験の値は，図 5 と同様に算出し，解析の值は，鉄筋要素とコンク リート要素の応力より算出している。なお, 解析のモーメント分布 は， $=40 \mathrm{~mm}$ で認められるように実験結果と良好な対応を示してい る。柱モーメント分布の勾配は，垂れ壁区間と空開口区間でほぼ同 じであるが; 腰壁区間で異なっている。その変化する位置は, 壁厚 が厚くなるとやや開口側に近くなる傾向があるが，壁端から $D_{C} / 2\left(D_{C}:\right.$ 柱せい)の範囲内に存在しており，その変化量(直線の折 れ曲がり)は，壁厚が厚くなる程大きい。特に，壁板の薄い場合， 壁圧縮力が小さいため $\left(C<Q_{C}\right)$, 柱モーメントの勾配は腰壁区間で 著しく変化せず, このことより見かけ上のクリアスパンが長くなり 曲价耐力が小さくなっている。なお， 左側柱と右側柱の柱モーメン 卜分布は，壁圧縮力の位置が違うのみで同様の性状であり，腰壁と 垂れ壁の抵抗状態は同一にモデル化できるといえる。

\section{2 柱一壁接合面における䄳み分布}

壁圧縮力について，図 12 に示した実験と解析における腰壁コン クリートの歪み分布から検討する。実験の歪みは，壁端から約柱せ い $\left(D_{C}\right)$ の幅で, かつ, 直線に近い分布で増加している。また, 壁端 部の歪みは, 壁厚に反比例して小さくなっている。そして, 壁板コ ンク.リートの圧壊が発生すると，歪みの発生区間は，壁の奥側へと 広がり，その広がりは主筋降伏後に著しくなる。解析においても， これら直線分布・分布の幅および壁厚の影響は，端部に歪みが集中 する傾向が見られるものの，同様に認められる。

\section{3 柱負担せん断力 $\left(Q_{d}^{j}\right)$ と壁圧縮力 $(C)$ および壁負担軸力 $(N w)$}

解析結果より求めた壁圧縮力(壁負担せん断力; $C$ ) 一柱負担せん断 力 $\left(Q_{C}\right)$ 関係及び壁負担軸力 $\left(N_{W}\right)$ 一壁圧縮力 $(C)$ 関係を図 13 に示寸。 柱負担せん断力は，コンクリート要素(せん断補強筋を含む)の水平 方向応力，壁負担せん断力と軸力は，柱一壁接合面に設定したクラ ックリンおよびダボバネの水平・鉛直方向応力より算出した。壁圧 縮力は, 曲げ降伏まで増加し続け, $\mathrm{t}=240,40,10 \mathrm{~mm}$ の值より, 壁板

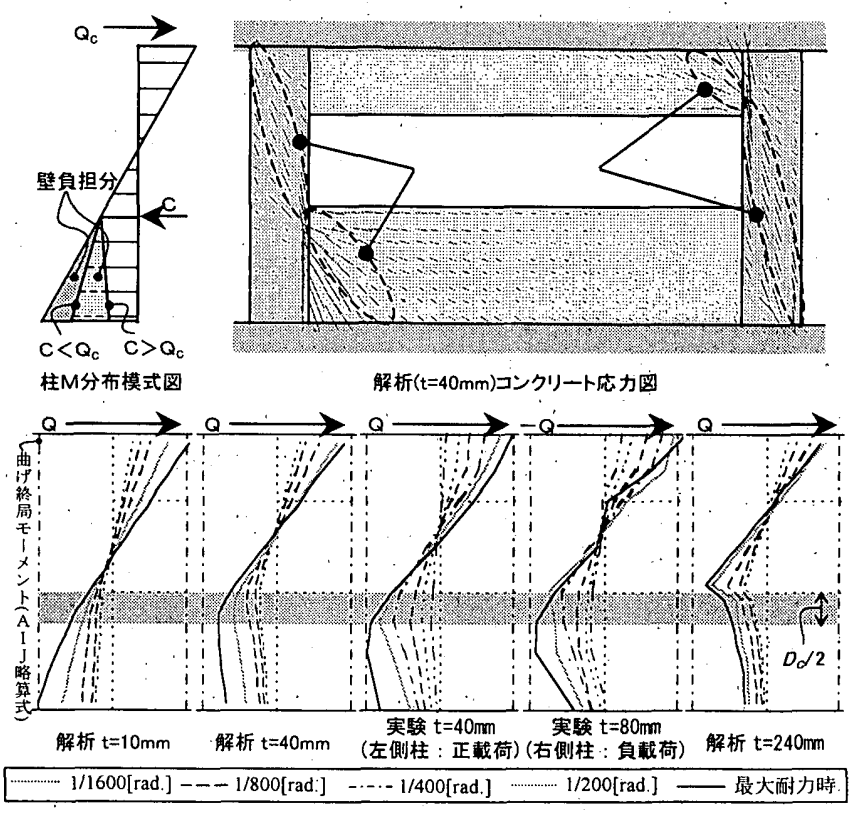

図 11 解析応力図および, 実験(No.2-1)・解析柱モーメント分布図

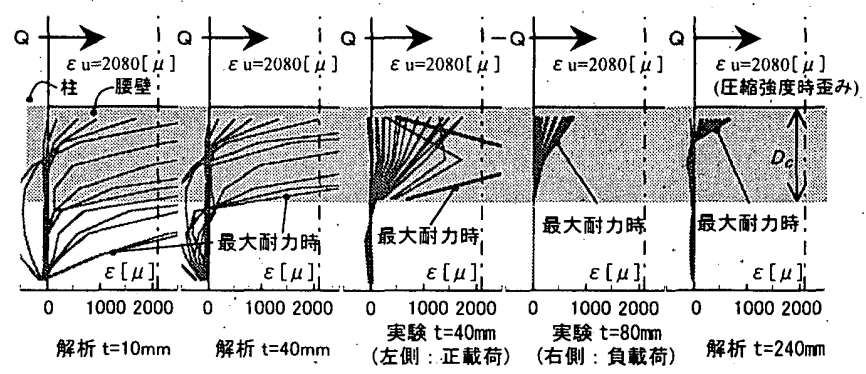

図 12 実験(No.2-1)・解析腰壁コンクリート圧樎歪み分布
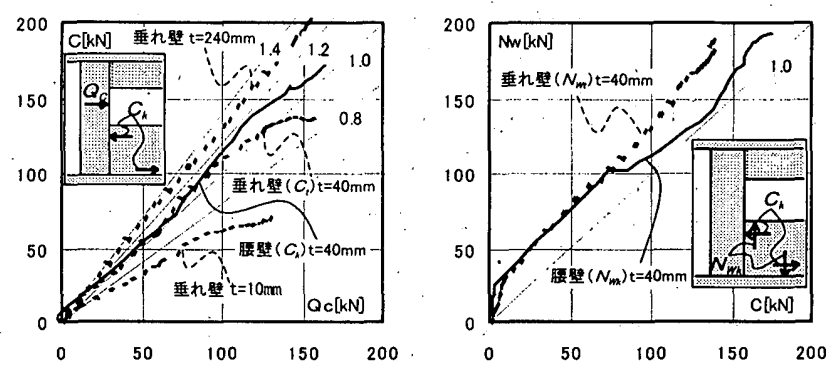

図 13 壁圧縮力一柱せん断力，壁軸力一壁圧縮力関係(解析)

が厚くなるほど柱せん断力に対する比が大きくなる傾向である。ま た，壁板の負担軸力は，壁圧縮力の増加量とほぼ同一に増加してお り; 壁板に圧縮束を想定すると，その角度は, 図 11 の主応力と同 じ $45^{\circ}$ と仮定できる。

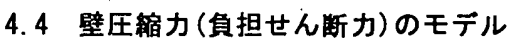

図 12 および図 13 に示した抵抗状態より，壁の圧縮力は，曲げ降 伏まで低下せず，壁コンクリート圧縮态力の重心位置もまた著しく 変化しないことになる。これらを簡略的に考え, 壁厚に関わらず壁 板コンクリートの歪み分布を直線に，コンクリートの応力度 $(\sigma)-$ ひずみ度 $(\varepsilon)$ 関係を線形と仮定して，応力状態を三角形分布で扱う こととする。従って, 壁圧縮応力の重心位置は, 図 12 より壁コシ クリート歪み分布の幅が $D_{C}$ であると推測されることから，曲げ降 伏まで変わることなく壁端から $D_{C} / 3$ の位置にあると仮定される。 


\section{5. 愎元カ包絡線の鲆価方法}

内部応力状態より，柱一壁板間の応力伝達状況を考慮した抵抗機 構のモデル化を行い，架構の復元力包絡線，特に剛性，耐力(破壊 モード)および変形性能の評価法について提案する。

架構の復元力包絡線は, 左右の柱の復元力包絡線をそれぞれ足し 合わせることで評価する。この柱復元力包絡線は，図 14 に示すよ うな Tri-linear でモデル化し, 評価項目は, 一次剛性 $\left(K_{C l}\right)$, 二次剛 性 $\left(K_{C_{2}}\right)$ ，曲げひび割れ発生荷重 $\left(Q_{C r r}\right)$ ，曲げ耐力 $\left(Q_{C_{y}}\right)$ ，せん断耐 力 $\left(Q_{C s u}\right)$ および限界変形 $\left(\delta_{C u}\right)$ とした。なお，剛性は厳密に評価す ると，柱一壁接合面にひび割れが発生する以前の剛性，つまり，壁 板に引張反力が生じる弾性㴊性が存在する。しかし，非常に小さい 荷重で柱一壁接合面にひび割れが発生するため, 弾性剛性は評価し ないものとした。また，限界変形角は，様々な定義 ${ }^{10)}$ が用いられ るが，本論文では，曲げ降伏後にせん断破壊が生じた点とした。

柱一垂れ壁間と柱一腰壁間の接合面に圧縮応力が発生し，梁が剛 体の場合，柱のモーメントおよびせん断力の分布は図 15 に示寸通 りとなる。この応力状態のモデル化により，柱の剛性・耐力を評価 する。なお，壁端からモーメントが最大となる位置までの距離 $\left(x_{k}\right.$, $\left.x_{1}\right)$ は，柱一壁接合面の态力分布を 3 角形と仮定したことから，壁厚 に関わらず $D_{C} / 3$ とする。ただし，壁高さ $\left(h_{k}, h_{t}\right)$ が柱せい $\left(D_{C}\right)$ よりも 小さい場合， $x_{k}, x_{t}$ は，壁高さの $1 / 3$ とする。また，壁板は，幅が $W$ とする圧縮束としてモデル化し，Wは柱せい $\left(D_{C}\right)$ と同一とする。

\section{1 网性}

\section{1 .11 次䣓性}

柱の剛性 $\left(K_{C}\right)$ は，壁板の取り付きを考慮した曲げ変形 $\left(\delta_{C m}\right)$ お よびせん断変形 $\left(\delta_{C s}\right)$ より(1)式で求められる。柱曲げ変形 $\left(\delta_{C m}\right)$

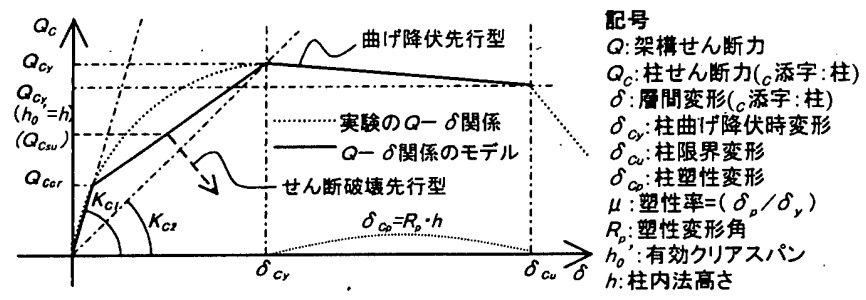

図 14 復元力包絡線評価模式図

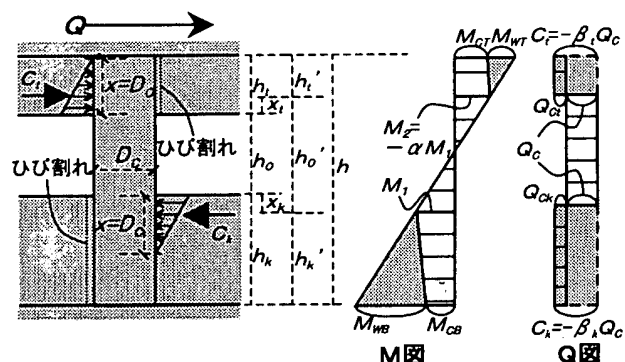

昌

$C_{t}:$ 垂れ壁压縮力

$C_{k}:$ 腰壁压縮力

$M_{c}:$ 柱負担モーメント

$M_{w}:$ 壁負担モーメント : 柱頭 ${ }_{B}$ : 柱脚

$M_{2}:$ クリアスパン端

部モーメント $\alpha=\left(-M_{1}, M_{1}\right)>0$ $A$ : 柱断面稳 $t$ : 暨 $W:$ 壁压綰束幅 $W$ : 壁压簿束幅 $j t$ : 柱主筋問距噰

Q图

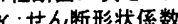

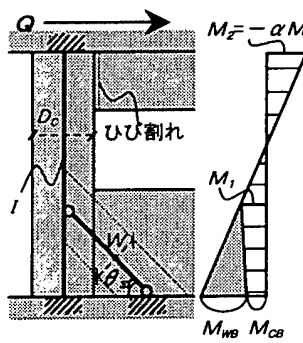
$Z$ : 柱断面係数 $\eta_{0}:$ 轴力比 $a_{s}$ : 柱引張鉄筋断面积 $\rho_{t}^{s}:$ 柱引張鉄第比 $\boldsymbol{p}_{w}$ : 拄せん断補強筋比 $\sigma_{y}$ : 柱主筋降伏強度 $\sigma_{y}$ : 柱せん断補強筋 降伏強度 コンクリート $E:$ ヤグ係数 $G:$ せん 断係数 $\nu_{0}:$ ポアソン比 n:ヤング保数比
は，部材軸方向( $y$ 方向)に柱モーメントが変化する事から，曲率 $(\varphi)$ を積分することで，(2)式のように求められる。また，柱せん断 変形 $\left(\delta_{C s}\right)$ は，せん断力からせん断変形角を算出し，曲げ変形と同 様に部材軸方向( $y$ 方向)で積分して(3)式のように求められる。

$$
\begin{aligned}
& K_{C}=\frac{Q_{C}}{\delta_{C m}+\delta_{C s}} \\
& \delta(\mathrm{y})_{C m}=\iint\{\varphi(\mathrm{y})\} \mathrm{dydy}=\iint\left\{\frac{M_{C}(\mathrm{y})}{E I}\right\} \mathrm{dydy} \\
& \delta(\mathrm{y})_{C s}=\int\left\{\frac{\kappa Q_{C}}{G A}\right\} \mathrm{dy}
\end{aligned}
$$

柱に壁板が両側に取り付く場合，図 15 から柱頂部の婅げ変形 $(\delta$ $C m l)$ とせん断変形 $\left(\delta_{C s l}\right)$ は，(4)式と(5)式で求められる。(4)，(5)式 は，(2)式および(3)式を用いて腰壁・開口部・垂れ壁の各区間で積 分し，境界条件から積分定数を求めることで算出した。

$$
\begin{aligned}
& \delta_{C m \mathrm{l}}=\delta(h)_{C m \mathrm{l}}=\frac{1}{6 E I}\left\{\left(1-\beta_{t}\right) h^{3}+3\left\{\left(\frac{1}{1+\alpha}-\dot{\beta}_{t}\right) h_{0}{ }^{\prime}+\left(1-\beta_{t}\right) h_{k}{ }^{\prime}\right\} h^{2}\right. \\
& \left.+3\left\{-\beta_{k} h_{k}{ }^{2}+\beta_{t}\left(h_{k}{ }^{\prime}+h_{0}{ }^{\prime}\right)^{2}\right\}+\left\{\beta_{k} h_{k}{ }^{3}-\beta_{t}\left(h_{k}{ }^{\prime}+h_{0}{ }^{\prime}\right)^{3}\right\}\right\} Q_{C} \\
& \delta_{C s 1}=\delta(h)_{C s 1}=\frac{\kappa}{G A}\left\{\left(1-\beta_{k}\right) h_{k}{ }^{\prime}+h_{0}{ }^{\prime}+\left(1-\beta_{t}\right) h_{t}{ }^{\prime}\right\} Q_{C} \\
& =\frac{7}{3 E A}\left\{\left(1-\beta_{k}\right) h_{k}{ }^{\prime}+h_{0}{ }^{\prime}+\left(1-\beta_{t}\right) h_{t}{ }^{\prime}\right\} Q_{C}
\end{aligned}
$$

$\beta_{k}$ と $\beta_{1}$ は，柱のせん断力 $\left(Q_{C}\right)$ と壁圧縮力 $(C)$ の比で, 1.0 の值 の時, 柱の負担せん断力と壁圧縮力が等しくなる。この壁板のせん 断力負担割合 $(\beta)$ は，柱の壁端における変形 $\left(\delta\left(h_{k}{ }^{\prime}\right) c\right)$ と壁圧縮束の 水平方向変形 $\left(\delta_{s t}\right)$ が一致することから，(6)式で求められる。なお， 圧縮束の角度 $\left(\theta_{s t}\right)$ は，壁板の負担せん断力と軸力がほぼ同じ值で 増加していることから $45^{\circ}$ とする。(6)式は，分数部分の分子第一 項が柱に純曲げが生じているときの変形, 分数部分の分子第二項が 壁圧縮束の変形であることから，柱と壁の剛性の大小で，柱のせん 断力と壁圧縮力の大小が決定されることを示している。 $\beta$ は， $\alpha$ の 変動による影響が小さいことから $\alpha=1$ とし，柱の断面二次モーメ ント $(I) を B_{C} D_{C}{ }^{3} / 12$ ，断面 $(A)$ を $B_{C} D_{C}$ ，とすると(6)'式で求められる。 (6)'式より $\beta$ は, 一般的な $\mathrm{RC}$ 架構 $\left(h / D_{C}: 3 \sim 4, h_{0}^{\prime} / D_{C}: 1 \sim 3\right.$, $\left.h_{k}{ }^{\prime} / D_{C}: 1 \sim 3, t / B_{C}: 1 / 6 \sim 1 / 2\right)$ を想定すると，0.8〜1.5 程度となる。

$$
\begin{aligned}
& \beta_{k}=1.00+\left(\frac{h_{0}{ }^{\prime} h_{k}{ }^{\prime 2}}{2(1+\alpha) E I}-\frac{h_{k}{ }^{\prime}}{t W E \cos \theta_{s t}}\right) /\left(\frac{h_{k}{ }^{3} 3}{3 E I}+\frac{\kappa h_{k}{ }^{\prime}}{G A}+\frac{h_{k}{ }^{\prime}}{t W E \cos \theta_{s t}}\right) . \\
& \beta_{1} \text { の場合, } h_{k} \text { を } h_{\text {。 }}, 1 /(1+\alpha) \text { を } \alpha /(1+\alpha) \text { とする } \\
& \beta_{k}=1.00+\left(\frac{3 h_{0}{ }^{\prime} h_{k}{ }^{\prime}}{D_{c}{ }^{2}}-\frac{1}{t / B_{c} \cdot \cos \theta_{s t}}\right) /\left(\frac{4 h_{k}{ }^{2}}{D_{c}{ }^{2}}+2.8+\frac{1}{t / B_{c} \cdot \cos \theta_{s i}}\right)
\end{aligned}
$$

なお，本論文の実験の様に，片側に壁板が取り付く外柱の場合 (図 15 下の図), 柱は，垂れ壁と腰壁のどちらか一方より圧縮力を 受ける事になる。この時の剛性, 耐力は, 右側柱については $\beta_{1}=0$, $h_{l}=0, h_{0}{ }^{\prime}=h_{1}+h_{0}+x_{k}$ として, 左側柱については, $\beta_{k}=0, h_{k}=0$, $h_{0}{ }^{\prime}=h_{k}+h_{0}+x_{l}$ とすることで求められる。

\section{1 .22 次用性}

柱の 2 次剛性 $\left(K_{C 2}\right)$ は，(7)式に示すように, 曲げ変形とせん断変 形にそれぞれ，曲げ剛性低下率 $\left(\alpha_{y}\right)$ およびせん断剛性低下率 $\left(\beta_{u}\right)$ を 用いて評価する。曲げ剛性低下率 $\left(\alpha_{v}\right)$ とせん断剛性低下率 $\left(\beta_{u}\right)$ は, 文献 11)より(8)式および(9)式を用いる。なお， $a$ は $h_{0}{ }^{\prime} ， \eta_{0}$ 仕荷重 
初期に導入した軸力比(本論文の実験では $1 / 6$ )として計算する。

$$
\begin{aligned}
K_{\mathrm{C} 2} & =\frac{Q_{\mathrm{C}}}{\delta_{C m 2}+\delta_{C s 2}}=\frac{Q_{C}}{\delta_{C m 1} / \alpha_{y}+\delta_{C s 1} / \beta_{u}} \\
\alpha_{y} & =\left(0.0432+1.635 n p_{t}+0.0434 a / D_{c}+0.325 \eta_{O}\right)\left(d / D_{c}\right)^{2} \\
\beta_{\mathrm{u}} & =0.461 p_{w w} \sigma_{y} / \sigma_{B}+0.13
\end{aligned}
$$

\section{2 各折点荷重（㶦力）および破挠モ一ド}

\section{2 .11 次折点（曲げひび割れ発生荷重）}

第一折点荷重 $\left(Q_{C c r}\right)$ は, クリアスパン端部のモーメント $\left(M_{l}, M_{2}\right)$ が(10)式6) の曲げひび割れ発生モーメントに達した時の荷重とし, 柱せん断力と壁圧縮力の比 $\left(\beta_{t}, \beta_{k}\right)$ を考慮して(11)式で求められる。

$M_{C c r}=0.56 \sqrt{\sigma_{B}} Z+N D_{C} / 6$

$Q_{C c r}=(1+\alpha) M_{C c r} / h_{0}{ }^{\prime}$ $\beta_{k} \geqq 1.0$

$Q_{C c r}=(1+\alpha) M_{C c r} /\left(\left(1-\beta_{k}\right) h_{k}{ }^{\prime}+h_{0}{ }^{\prime}\right): \beta_{k}<1.0\left(\beta_{1} \text { の場合も同様 }\right)^{\prime} \cdot \cdots$

\section{2 .22 次折点（曲げ耐力およびせん断柇力），破丧モード}

第二折点荷重 $\left(Q_{C y}\right)$ は，クリアスパン端部のモーメント $\left(M_{1}, M_{2}\right)$ が(12)式6) の曲げ降伏モーメント $\left(M_{C y}\right)$ に達した荷重とし，柱せん 断力と壁圧縮力の比 $\left(\beta_{l}, \beta_{k}\right)$ を考慮して $(13)$ 式で求められる。

また，せん断耐力 $\left(Q_{C s u}\right)$ は，鉄筋コンクリート造建物の終局強度 型耐震設計指針 ${ }^{12)}$ におけるせん断耐力式 A 法の.非勒性式を(14)式 のとおり用いる。なお，クリアスパンを $h_{0}{ }^{\prime}$ とするが， $h$ を用いる 場合には，より安全側の評価となる。

$$
\begin{aligned}
& M_{C y}=0.8 a_{s} \sigma_{y} D_{c}+0.5 N D_{c}\left(1-N /\left(B_{c} D_{c} \sigma_{B}\right)\right) \\
& \text { (軸力の変動は考慮しない, } N \leqq 0.4 B_{C} D_{C} \sigma_{B} \text { ) } \\
& Q_{C y}=2 M_{C y} / h_{0}^{\prime} \quad: \dot{\beta}_{k} \geqq 1.0 \\
& Q_{C y}=2 M_{C y} /\left(\left(1-\beta_{k}\right) h_{k}{ }^{\prime}+h_{0}{ }^{\prime}\right): \beta_{k}<1.0 \text { ( } \beta_{1} \text { の場合も同様) } \\
& Q_{C s u}=B_{c} j_{t} p_{w w} \sigma_{y} \cot \phi+\tan \theta(1-\beta) B_{c} D_{C^{\nu}} \sigma_{B} / 2 \\
& \tan \theta=\frac{\sqrt{h_{0}^{\prime 2}+D_{c}{ }^{2}}-h_{0}^{\prime}}{D_{C}} \quad \nu=v_{0}=0.7-\frac{\sigma_{B}}{200} \quad \beta=\frac{\left(1+\cot ^{2} \phi\right) p_{w w} \sigma_{y}}{\nu \sigma_{B}} \\
& \cot \phi=\min \left(2.0, j_{t} /\left(D_{C} \tan \theta\right), \sqrt{\nu \sigma_{B} /\left(\mathrm{p}_{w w} \sigma_{y}\right)-1.0}\right) \text { 勒性式: } \nu=\left(1.0-15 R_{p}\right) \nu_{0} \\
& \theta: \text { アーチ機樥の圧縮束角度 } v: \text { :コンクリート圧縮强度有效保数 } \\
& \phi: \text { :ラス機粠の圧樎束角度 } \beta \text { : コンクリート圧縮力のトラス機满負担比率 }
\end{aligned}
$$

破壊モードば，柱曲げ降伏先行または柱せん断破壊先行につい て判定し，その判定は，曲げ耐力計算值とせん断耐力計算值の比で あるせん断余裕度 $\left(Q_{C s u} / Q_{C y}\right)$ より行う。破壊モードの判定は，せん 断余裕度が 0.8 である No.2-1 が曲げ降伏したことから， 0.8 以上 の余裕度で曲げ降伏先行型になるものとする。

\section{3 夜形性能}

腰壁および垂れ壁が付帯する柱の変形性能は, 壁板コンクリート 圧壊の有無によって異なる。ここでは，柱の変形性能は，壁板が圧 壊しない場合，短柱として評価し，壁板が圧壊する場合は，長柱と して評価する。壁板コンクリート圧壊の有無は, 壁板圧壊強度 $\left(C_{c}\right)$ と柱の曲げ耐力 $\left(Q_{C y}\right)$ の大小により判断する。壁板圧壊強度は, 壁 板に三角形の忘力分布が存在するものと仮定して(15)式で計算し, この值より曲げ降伏耐力 $\left(Q_{C}\right)$ が大きい場合, 柱の変形性能は, 短 柱の時よりも向上すると判断する。

$$
C_{c}=t D_{C} \sigma_{B} / 2
$$

壁板が圧壊する場合の限界変形 $(\delta u)$ は， $h_{0}{ }^{\prime}=h$ とした長柱の曲げ 耐力((12), (13)式で計算) と文献 12)におけるせん断耐力式 A 法勒性 式 $\left(h_{0}{ }^{\prime}=h\right.$ として(14)式で計算)の值が, 同じになる塑性変形角 $R_{p}$ よ り(16)式で求められる(図 14)。

$$
\delta_{C u}=\delta_{C y}+\delta_{C p}=\delta_{C y}+R_{p} \cdot h
$$

この時の変形性能は，壁板が存在しない長柱の場合と同一になる が,この評価法は，長柱の場合でも非常に安全側であること，また， 壁板コンクリート圧壊の有無を安全側に評価していることから，結 果として，十分安全側に評価できると考えられる。

以上の手法により柱のせん断力ー水平変位包絡線を求めることで 架構のせん断力ー水平変位関係を評価する。

\section{6. 權造性能評価方法の道合性}

ここでは，提案する構造性能評価方法の適合性について検証する。

\section{1 本研究の実倹との適合}

以上の評価方法を本論文の実験・解析結果より検証する。図 16 にせん断力一層間変位関係包絡線における計算值と実験值の比較を 示す。計算值は, 左右にある 2 本の柱のせん断力一層間変位関係包 絡線を足し合わせることで求めており，せん断破壊した時点で保持 せん断力が消失するものとした。せん断力一層間変位関倸において， 本論文の計算方法は，変形能を大きく安全側に評価しているが，概 ね実験結果とよい適合性を示している。また，壁厚の変化による剛 性の上昇や，壁板が非常に薄くなった場合に生じる曲げ耐力の堿少 も非常に良く表現する結果となっている。特に，曲げ耐力は，既往 の提案式 222，23.)よりも簡便な方法で精度良く評価できるといえる。

\section{2 既往研究の実験との適合}

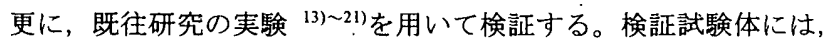
垂れ壁・腰壁が架構内に存在する，または，垂れ壁・腰壁が柱に取 り付く試験体を抽出した。試験体の破壊モードは，全て曲げ降伏 (曲げ破壊)またはせん断破壊である。試験体は，純 RC 試験体のみ で，連続纎維で補強された試験体を除いた。また：基準試験体であ る柱試験体(壁が付帯しない試験体)の曲げ耐力が著しく計算値(AIJ 曲げ略算)と異なる論文の(比較值が 0.85 以下または 1.15 以上)試験 体も除いた。なお，既往研究では；耐力に主眼が置かれることが多 く，変形について報告されているものは少ない。そこで，ここでは，
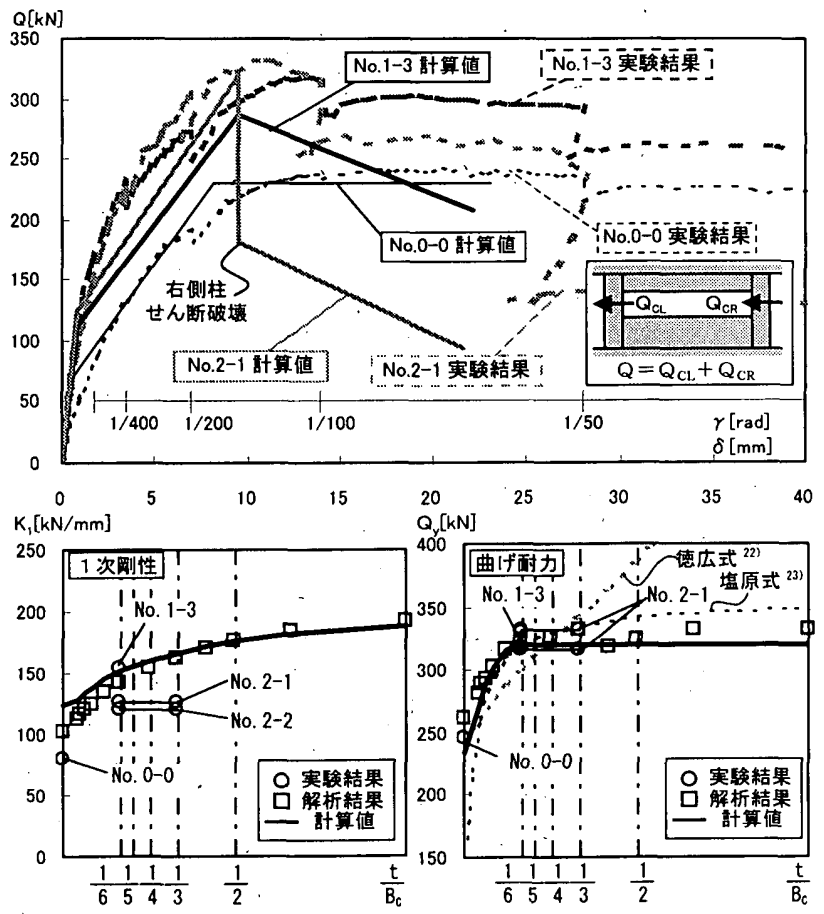

図 16 計算値実験値比較 

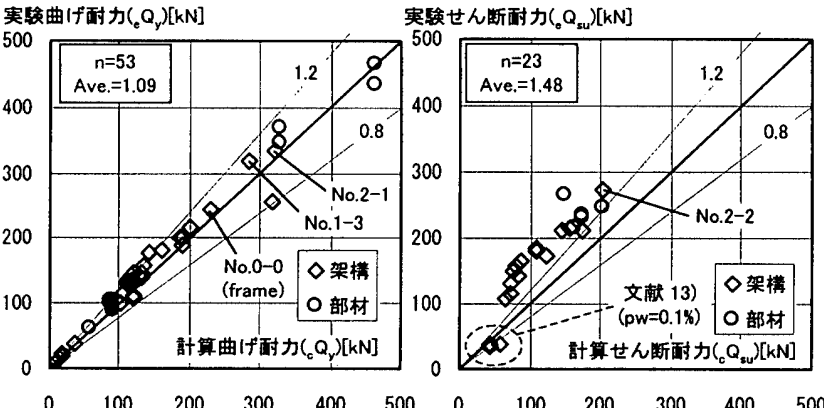

図 17 せん断及び曲げ耐力実験值・計算値比較図
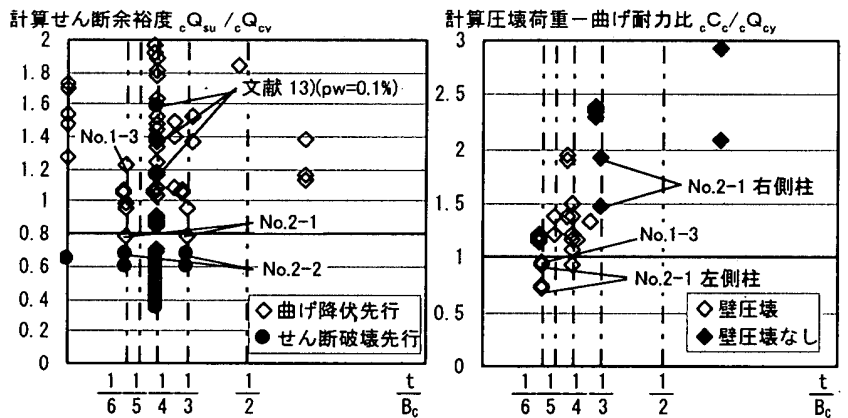

図 18 柱破壇モードおよび壁板圧壊判定図

曲げ耐力, せん断耐力，柱破壊モードの判定および壁板圧壊による 変形能の向上について検証する。図 17 に曲げ耐力 $\left(e Q_{y},{ }_{c} Q_{y}\right)$ とせん 断耐力 $\left.{ }_{e} Q_{s u}, c Q_{s u}\right)$ の実験值と計算値の比較, 図 18 に計算柱せん断 余裕度 $\left({ }_{c} Q_{s u} /_{c} Q_{c v}\right)$ と柱破壊モードの関係, 計算壁板圧壊強度一柱曲 げ耐力比 $\left({ }_{c} C_{c} d_{c} Q_{c y}\right)$ と壁板圧壊(勒性能の向上)の関係について示す。

\section{2.1 耐力および破楼モードの判定}

図 17 に見られるように，曲げ耐力計算値は，実験值に対して 1.09 と良好な対応となり，また，せん断耐力計算值も安全側であ るが概ね実験值と対応している。そして，図 18 の計算せん断余裕 度と破壊モードの関係から，せん断と曲げの破壊モードの境界は， 壁厚に関倸なくせん断余裕度が 0.8 の時と判定できる。

\section{2.2 壁板圧棲の有無 (変形能の向上)}

壁板圧壊の有無は，論文中で壁板コンクリート圧壊が報告されて おり，かつ， Q- $\delta$ 関倸で緩やかな耐力低下と純ラーメン以上の変 形能が確実に確認できるものについて取り上げており，これらを短 柱よりも変形能が向上したとみなした。図 18 の通り, 壁板圧壊強 度が柱曲げ降伏耐力よりも小さい場合(比較值 1.0 以下), 曲げ降伏 後に勒性能を有する性能となる。よって, 壁板を圧壊させる場合は, 本方法によって，壁板の圧壊を判定すればよいといえる。

以上より，本論文の評価法は，垂れ壁・腰壁的挙動を示す非構造 壁を内蔵する架構の構造性能を良好に表現できると考えられる。

\section{7. 結論}

本論文では，構造体(柱)に充分なせん断補強がなされた場合，非 構造壁を内蔵する架構は，非構造壁の存在が構造体に悪影響を及ぼ さず，剛性，耐力およびエネルギー吸収量が純ラーメンよりも上昇 する性状となることを示した。これにより，非構造壁を内蔵する架 構の設計は，柱と壁板の応力伝達を敢えて無くす方法ではなく，壁 板の破壊を許容した設計法も選択が可能であることを示した。本論 文では特に, 垂れ壁・腰壁的な挙動を示す非構造壁を内蔵する架構
を取り上げ，構造性能（剛性，耐力，破壊モードおよび変形能）の 評価方法を提案した。本手法は，実験および解析から柱と壁板の応 力伝達状況を顕在化してせん断抵抗機構のモデル化を行うことで構 築しており，実験を良く表現する事を示した。

\section{青文啾}

1) 日本建築学会：1968 年十勝沖地震被害調查報告, 昭和 43 年 12 月, 1978 年宮城沖地震災害調查報告,昭和 55 年 2 月, 1995 年兵庫県南部地震鉄 筋コンクリート造建築物の地震被害調查報告書, 1997.3 等

2）1995 年兵庫県南部地震鉄笳コンクリート造建築物の被害調查溇告書, 日 本建築学会，第 IV 編集合住宅 pp. 69,163, 第VI編非構造部材 pp.67〜 76,pp.31,39,102 103, 1997.3,

阪神・淡路大震災と今後の $\mathrm{RC}$ 構造設計一特徽的被害の原因と設計人の 提案一, 日本建築学会, pp.430 435, 1998.10 等

3）日本建築センター：建築物の構造規定 1997 年版,1997

4）日本建案防災協会：既存鉄筋コンクリート造建築物の耐震診断基淮 耐覀 改修設計指針・同解説, 1990

5) 日本建築学会耐震壁小委員会二次壁ワーキンググループ: 構造目地を設け た鉄笳コンクリート造二次壁に関する研究資料,昭和 63 年 3 月

6) 日本建築学会 : 鉄筋コンクリート構造計算規淮・同解説, 1999

7) 張愛暉,野口博：RC 造柱のせん断終局強度に及ぼす軸力の影響に関する解 析的研究,コンクリート工学年次論文報告集,Vol.12,No.2,pp.329〜332

8) Darwin D. and D. A. Pecknold : Inelastic Model for Cyclic Biaxial Loading of Reinforced Concrete, SRS No.409, Civil_Engineering Sudies, University of Illinois, 1974.7

9）大淵英夫,松崎育弘，中野克彦：ずれ変形を考慮したプレキャスト部材接合 面におけるせん断伝達に関する研究，日本建築学会構造系論文報告集， 491 号 pp.97〜pp.104, 1997.1

10）日本コンクリートエ学：コンクリート構造物の勒性とその評価法に関す るコロキウム, 1988.3

11）菅野俊介：鉄筋コンクリート部材の復元力特性に関する実験的研究，東 京大学博士論文, 1970.12

12）日本建築学会：鉄䈘コンクリート造建物の終局強度型耐震設针指針・同 解説, 1990

13) 大久保全陸：腰壁，垂机壁，袖壁付き鉄筋コンクリート骨組の㴊性，強 度および履歴特性に関する研究，日本建築学会論文報告集，pp.19〜25， 昭和 46 年 8 月

14) 武田筧：鉄筋コンクリート造腰壁，垂れ壁付きラーメンの耐力及び変形 性状に関する実験的研究（その2），日本建築学会大会学術講演梗概集， pp. 1281 1282, 昭和 54 年 9 月

15）武田寛：鉄筋コンクリート造腰壁，垂れ壁付きラーメンの耐力及び変形 性状に関する実験的研究（その 3 ），日本建築学会大会学術講演梗概集， pp.1637 1638, 昭和 55 年 9 月

16) 武田寛：鉄筋コンクリート造腰壁，垂れ壁付きラーメンの耐力及び変形 性状に関する実験的研究 (その 4), 日本建築学会大会学衔講演梗概集, pp.1439 1440, 昭和 56 年 9 月

17) 武田寛：鉄筋コンクリート造雑壁付き柱の耐力及び变形性状に関する実 験的研究, 日本建築学会大会学術講演梗概集, pp. 1753 1754, 昭和 59 年 10 月

18) 荒川卓,他 5 名： R C 柱の繰返し挙動に及ぼす腰壁,垂九壁の厚さと偏心付 加の影響, 日本建築学会大会学術講演梗概集, pp.1755 1758,昭和 59 年

19) 荒川卓,他 3 名: 繰返し荷重を受ける腰壁, 垂れ壁付き RC 柱の㑉性と終 局強度について，コンクリート工学年次講演論文集,pp. $565 \sim 568,1985.10$

20）宇野功一,松崎育弘，中野克彦，杉山智昭: 腰壁 - 垂れ壁付き RC: 柱が面外 方向に荷重を受けた場合の構造性能に関する実験研究, 日本:コンクリー 卜工学年次学術講演集, pp.409 pp.414,2000.6

21) 水井仁,金久保利之, 神野靖夫, 伊藤功一：壁付き R C 柱の新しい耐震補强 工法(CF アンカー)の開発 その 4 , 日本建筑学会大会学術講演梗概集, pp. $27 \sim 28,1999.9$

22) 徳弘育夫,久徳环磨：鉄筋コンクリート造垂壁・腰壁付き柱の終局耐力に 影響を及ほす構造因子に関する研究，日本建築学会大会学術講演梗概集， pp.395 396, 昭和 61 年 8 月

23）村上靖佳,楠原文雄,塩原等,小谷俊介：腰壁付き鉄䈘コンクリート造短柱 の腰壁圧壊强度に関する研究，日本建築学会大会学術謱演梗概集， pp.253 256, 1998.9

24）杉山智昭笠原美幸,植村政彦、福山洋,中野克彦,松崎育弘：シート状炭素緎 維により補強された R C 造非構造壁の構造性能に関する実験的研究, 日 本建築学会大会学術講演梗概集, C-2pp. 61 64, 1999.9

25）杉山智昭,中野克彦,松崎育弘：非構造壁を内蔵する鉄筋コンクリート造架 構の構造性能に関する実験的研究, 日本建築学会大会学術講演梗概集, C-2pp. 555 556, 2000.9

（2001年 5 月 10 日原稿受理，2001年10月10日採用決定 